\title{
Dipropylcyclopentylxanthine triggers apoptosis in Jurkat $T$ cells by a receptor-independent mechanism
}

\author{
Maribel Mirabet ${ }^{1}$, Josefa Mallol ${ }^{1}$, Carmen Lluis ${ }^{1}$ and Rafael \\ Franco $^{1,2}$ \\ ${ }^{1}$ Departament de Bioquímica i Biologia Molecular, Facultat de Química, \\ Universitat de Barcelona, Catalonia, Spain \\ 2 correspondence author: Rafael Franco, Departament de Bioquímica i Biologia \\ Molecular, Facultat de Química, Martí Franquès 1, 08028 Barcelona, Spain. \\ tel: 343-4021208; fax: 343-4021219; email: r.franco@sun.bq.ub.es
}

Received 24.3.97; accepted 12.6.97

Edited by M.L. Gougeon

\begin{abstract}
1,3-Dipropyl-8-cyclopentylxanthine (DPCPX), a xanthine analog used as selective antagonist of adenosine receptors, caused apoptosis in a human leukemia T cell line. Jurkat cells treated with DPCPX underwent apoptosis as demonstrated by flow cytometry, by DNA fragmentation and by accumulation of histones, H2A, H2B, H3 and H4, in the nucleoplasm of cells. Cell cycle and cell sorting analyses indicated an arrest of cells in $G_{2} / M$ followed by the appearance of apoptotic cells in $G_{1}$ and $\mathrm{G}_{2} / \mathrm{M}$ phases. The mechanism of programmed cell death does not seem to be mediated by signal transduction events at the plasma membrane since it did not involve activation of cell membrane receptors and modification of the intracellular levels of $\mathrm{Ca}^{2+}$ or cAMP. Apoptosis by incorporation into DNA of a derivative of DPCPX is suggested in basis of the presence of radioactivity label in the DNA obtained from cells preincubated with $\left[{ }^{3} \mathrm{H}\right] \mathrm{DPCPX}$.
\end{abstract}

Keywords: apoptosis; 1,3-Dipropyl-8-cyclopentylxanthine; T lymphocytes; leukemia; therapy

Abbreviations: BSA, bovine serum albumin; DPCPX, 1,3Dipropyl-8-cyclopentylxanthine

\section{Introduction}

Apoptosis (programmed cell death) and necrosis are the two mechanisms by which nucleated eukaryotic cells die (Duvall and Wyllie, 1986). Necrosis is considered as a pathological event in response to major perturbations in the cellular environment. Necrotic cells swell leading to rupture of plasma and organelle membranes, release of cell content and loss of organized structure (Eastman et al, 1994). On the other hand, apoptosis is considered as a physiological process taking part in homeostatic regulation; in this way death is necessary in normal tissue turnover (Duvall and Wyllie, 1986; McConkey et al, 1989; Rothenberg, 1990). The mechanism(s) of apoptosis may differ from one system to another. In most cases, apoptosis follows an increase in $\left[\mathrm{Ca}^{2+}\right]_{\mathrm{i}}$, requires protein synthesis, and is manifested by endogenous nuclease activation which results in DNA fragmentation. At the optical microscopy level, apoptosis can be suspected in cells presenting a nucleus with condensed chromatin (reviewed in McConkey et al, 1990; Cohen, 1993).

Purine compounds have been widely used in the therapy of proliferative diseases. 6-mercaptopurine and 6-thioguanine were among the first to be used (Hitchings, 1991). These compounds are metobolized in the cell and some of the resulting products interfere with DNA synthesis. Thus, replication of DNA in cancer cells does not occur and tumor cell proliferation is blocked. Recent studies have demonstrated that several purine analogs used as anticancer drugs are cytotoxic because they induce apoptosis in proliferating cells. Thus, 2 -chloro- 2 -deoxyadenosine and $9-\beta$-D-arabinosyl-2-fluoroadenine are potent inducers of apoptotic death in lymphocytes from patients with chronic lymphocytic leukemia (Carrera et al, 1991; Robertson et al, 1993). The molecular mechanism of death induction is not known but Hentosh and Grippo (1994) have presented evidence that 2chloroadenine incorporated into DNA may inhibit daughter strand synthesis thus contributing to the cytotoxic effects of 2-chloro-2'-deoxyadenosine and its triphosphate derivative (cladribine), which is also used as an antileukemic agent.

The purine nucleoside adenosine is able to cause apoptosis in human thymocytes by a mechanism that involves interaction with specific adenosine receptors located on the cell surface and which are coupled to heterotrimeric $G$ proteins. Agonists to these receptors produce variations in the intracellular level of second messengers, cAMP and $\mathrm{Ca}^{2+}$, that seem responsible for the activation of the apoptotic events (Kizaki et al, 1990; Szondy, 1994). In contrast to these findings in non malignant human $\mathrm{T}$ cells, adenosine triggers apoptosis in human leukemia HL-60 cells by a receptor-independent mechanism that requires the entry of the nucleoside to the cell (Tanaka et al, 1994).

In this paper we present evidence that a xanthine derivative, 1,3-dipropyl-8-cyclopentylxanthine (DPCPX), activates the apoptotic machinery in Jurkat cells, which derive from a human acute $\mathrm{T}$ leukemia.

\section{Results \\ DPCPX-induced apoptosis in Jurkat cells}

The xanthine derivative, 1,3-dipropyl-8-cyclopentylxanthine (DPCPX), is used as selective antagonist of $A_{1}$ and $A_{2 b}$ adenosine receptors present on the surface of cells. In $\mathrm{T}$ lymphocytes, the most abundant adenosine receptor is the $A_{2 b}$ subtype, which mediates increases in cAMP, further potentiated by activation via the receptor for the antigen (Fredholm and Sandberg, 1983; Kvanta and Fredholm, 1991). 
We were interested in determining whether agonists or antagonists of adenosine receptors modulate $T$ cell activation. We found that $\mathrm{N}$-ethylcarboxamido adenosine (up to $250 \mu \mathrm{M}, 24-72 \mathrm{~h}$ period), an agonist of $\mathrm{A}_{2 \mathrm{~b}}$ receptors, did not modify the proliferative capacity of Jurkat cells whereas DPCPX had an antiproliferative effect. In fact, concentrations of $10 \mu \mathrm{M}$ DPCPX or higher led to a marked decrease in the number of cells and in the $\left[{ }^{3} \mathrm{H}\right]$ thymidine incorporation. The percentage of reduction in the number of cells in chronic treatments (up to $144 \mathrm{~h}$ ) with $25 \mu \mathrm{M}$ DPCPX approached $90 \%$. This was not due to a slower rate of proliferation but to cytotoxicity since it was accompanied by a reduction of the viability of the cells. These effects of DPCPX were receptor- independent since they were not antagonized by $\mathrm{N}$ ethylcarboxamido adenosine.

The presence of apoptotic bodies in cells treated for $48 \mathrm{~h}$ with $25 \mu \mathrm{M}$ DPCPX led to the suspicion that the reagent initiated a death cell program in Jurkat $T$ cells (Figure 1). The laser-beam flow cytometric analysis of untreated cells indicated a single population whereas treated cells presented two populations, one similar to that of untreated cells and the other displaying decreased forward light scattering (FSC) and increased side light scattering (SSC) (Figure 1). The combination of high side scattering and low forward scattering is an indication of apoptotic cells (Darzynkiewicz et al, 1992; Dive et al, 1992).

\section{CONTROL}
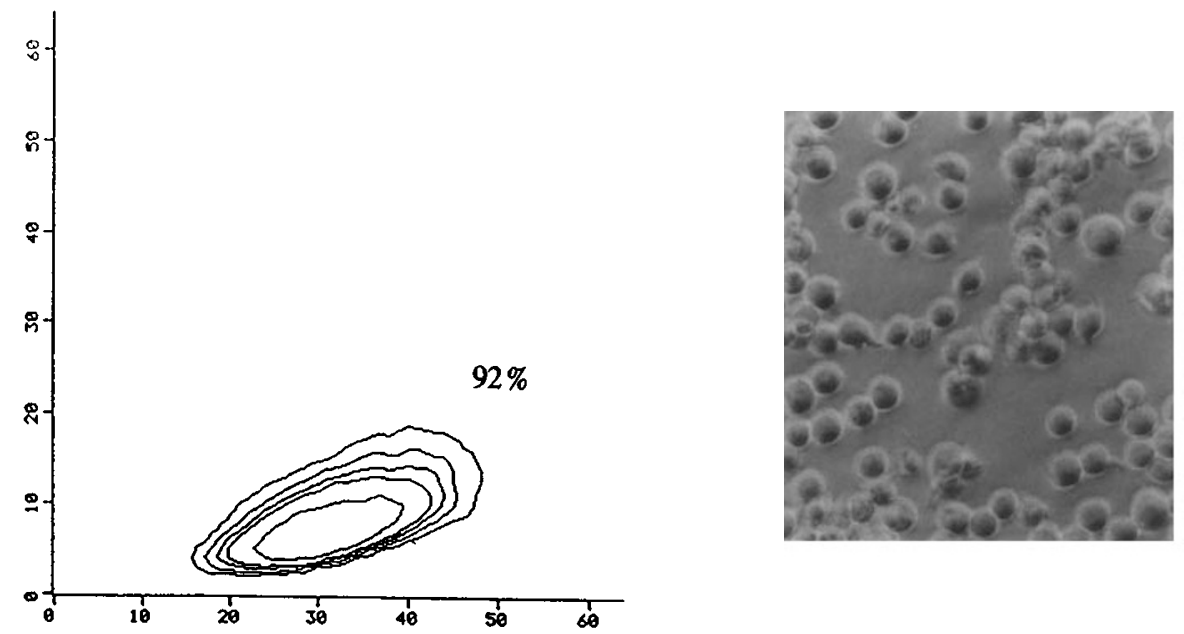

崖

DPCPX $25 \mu \mathrm{M}$
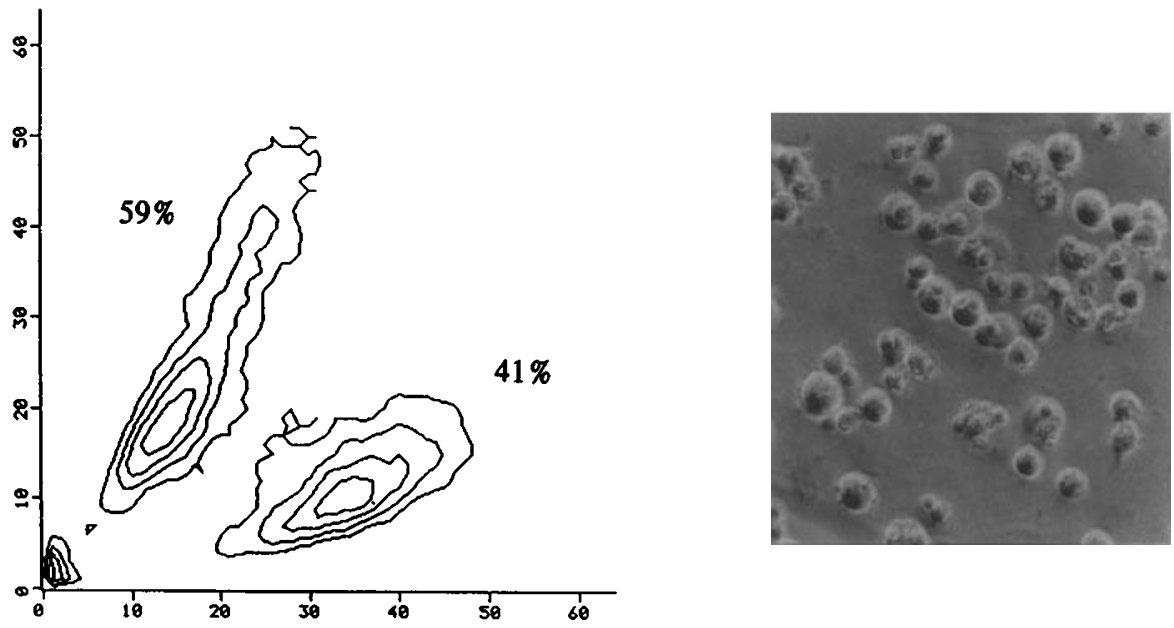

FSC

Figure 1 Morphology of DPCPX-treated Jurkat cells. The forward (cell size) versus side scatter (properties of cytoplasmic and nuclear components) distribution of naïve Jurkat cells (upper part) or cells treated with $25 \mu \mathrm{M} \mathrm{DPCPX}$ for $48 \mathrm{~h}$ (lower part). The percentage of cells in each population respect to the total amount of cells analyzed by flow cytometry is given. Inserts: micrographs representing the total population $(300 \times)$ 
To confirm the presence of DPCPX-induced apoptosis in Jurkat cells, a set of complementary experiments was carried out. First, the effect of DPCPX upon Jurkat's cell cycle was analyzed. For this purpose the DNA of the cells (untreated or treated) was labeled with Hoechst 33342 (see Materials and Methods). In control cells the pattern did not change significantly over time; the percentage of cells in $G_{0} / G_{1}$ phase was 37-44 whereas the percentage in $S$ phase was 41-44. Treatment of cells with DPCPX led to a progressive accumulation of fluorescence near the $\mathrm{Y}$-axis due to DNA fragments released from dead cells. After $8 \mathrm{~h}$ of treatment, DPCPX led to the accumulation of cells in the $\mathrm{G}_{2} / \mathrm{M}$ phase (Figure 2). At a longer time (24 h) a large proportion of DPCPX-treated cells was found in a peak previous to that denoting the $G_{1}$ phase (Figure 2). This peak, which is characteristic of apoptotic cells, corresponds to cells with fragmented DNA (Gorzyca et al, 1993; Belloc et al, 1994; Zhu and Anasetti, 1995). At $48 \mathrm{~h}$ of treatment, the peak corresponding to cells with fragmented DNA was also present. A fourth peak prior to that representing the $\mathrm{G}_{2} / \mathrm{M}$ phase appeared after 24 or $48 \mathrm{~h}$ of treatment. Thus, the xanthine analog induced the appearance of a double cell cycle with the two standard peaks representing $G_{1}$ and $\mathrm{G}_{2} / \mathrm{M}$ phases and two extra peaks. It should be noted that similar results were obtained when, instead of Hoechst 33342, either 4,6-diamidino-2-phenylindole (DAPI) or propidium iodide were added to fixed Jurkat cells.

As described by Belloc et al (1994), the flow cytometric method using Hoechst 33342 is useful for simultaneous cell cycle analysis and apoptosis determination. Fluorescence emission at $395 \mathrm{~nm}$ and $675 \mathrm{~nm}$ in control cells (Figure 3A top) corresponds to cells in phases $G_{1}$ (population B2), $G_{2} / M$ (population B1) and $S$. An image of these untreated cells labeled with both Hoechst 33342 and propidium iodide indicates no sign of cell death (Figure $3 A$ ). The image of DPCPX-treated cells labeled in the same manner indicates the presence of apoptotic cells, some already presenting highly permeable plasma membranes. The presence of cells with a pycnotic nucleus but with an intact plasma membrane, i.e. not labeled with propidium iodide, is an indication that death comes as a consequence of apoptosis. Analysis of fluorescence at $395 \mathrm{~nm}$ and $675 \mathrm{~nm}$ in treated cells revealed B1, B2, B1' and B2' populations (See Figure $3 A$ bottom); two were similar to those found in control cells (B1 and B2) whereas the other two (B1' and B2') emitted more fluorescence at $675 \mathrm{~nm}$. A fifth population corresponding to small DNA fragments in apoptotic bodies or released to the culture medium was located near the axis origin and was not further analyzed. A cell sorter permitted the isolation of the four different populations, which were then observed under an epifluorescence microscope. All cells among B1 and B2 populations had a normal appearance. In contrast, all cells of B1' $^{\prime}$ and B2' $^{\prime}$ populations were apoptotic, as indicated by the pycnotic nucleus (Figure $3 \mathrm{~B}$ ). Thus, DPCPX produced apoptotic B1' cells that probably derive from cells initially in the $G_{1}$ phase and apoptotic B2' cells that probably derive from cells initially in $G_{2} / M$ phase. The number of cells having a pycnotic nucleus increased with DPCPX treatment in a dose-dependent fashion and was evident already at $5 \mu \mathrm{M}$ (at 24 or $48 \mathrm{~h}$ of treatment).

Apoptosis was further confirmed by the DPCPX-induced appearance of the fragmented DNA ladder and of nucleosomal histones $(\mathrm{H} 2 \mathrm{~A}, \mathrm{H} 2 \mathrm{~B}, \mathrm{H} 3$ and $\mathrm{H} 4)$ in the nucleoplasm of treated cells (Figure 4).

\section{Mechanism of DPCPX-induced apoptosis}

To determine whether the DPCPX-induced apoptosis was mediated by signal transduction events, the intracellular level of two second messengers, $\mathrm{Ca}^{2+}$ and CAMP, was measured in control and treated cells. The xanthine analog (up to $25 \mu \mathrm{M}$ ) did not produce any increase in the intracellular concentration of $\mathrm{Ca}^{2+}$ or any variation in the
CONTROL

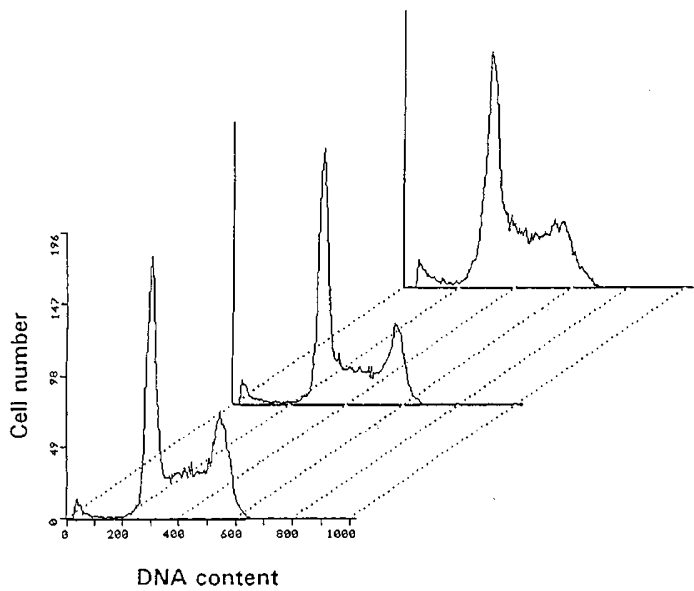

$\mathrm{DPCPX} 25 \mu \mathrm{M}$

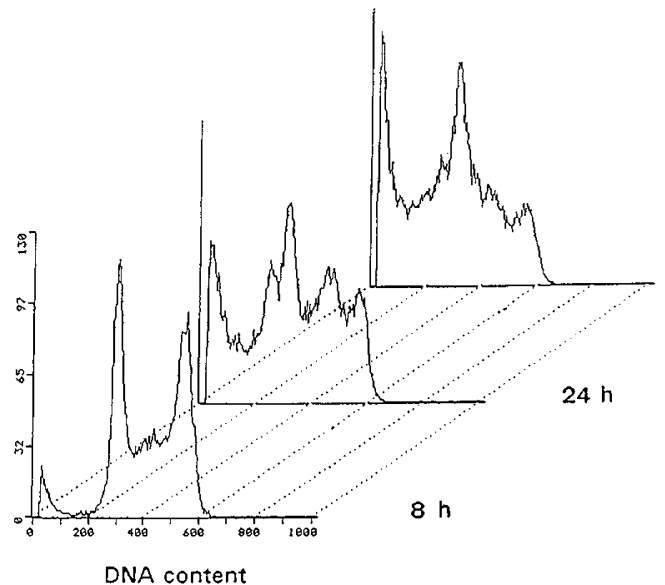

$48 \mathrm{~h}$

Figure 2 Cell cycle analysis of untreated or DPCPX-treated cells. Cells were treated with DPCPX for the indicated times and DNA was stained with Hoechst 33342 as described in Materials and Methods 
level of cAMP. Since xanthines are often used as inhibitors of CAMP phosphodiesterases, we hypothesized that DPCPX could activate the apoptotic machinery by inhibiting phosphodiesterases IV and/or VII, which are present in
Jurkat cells. To confirm this hypothesis we tested two phosphodiesterase inhibitors $(500 \mu \mathrm{M}$ rolipram or $500 \mu \mathrm{M}$ 1,4-dihydro-2-methyl-6-oxo-3,4-bipyridine-5-carbonitrile-milrinone-) as possible inducers of programmed cell death.
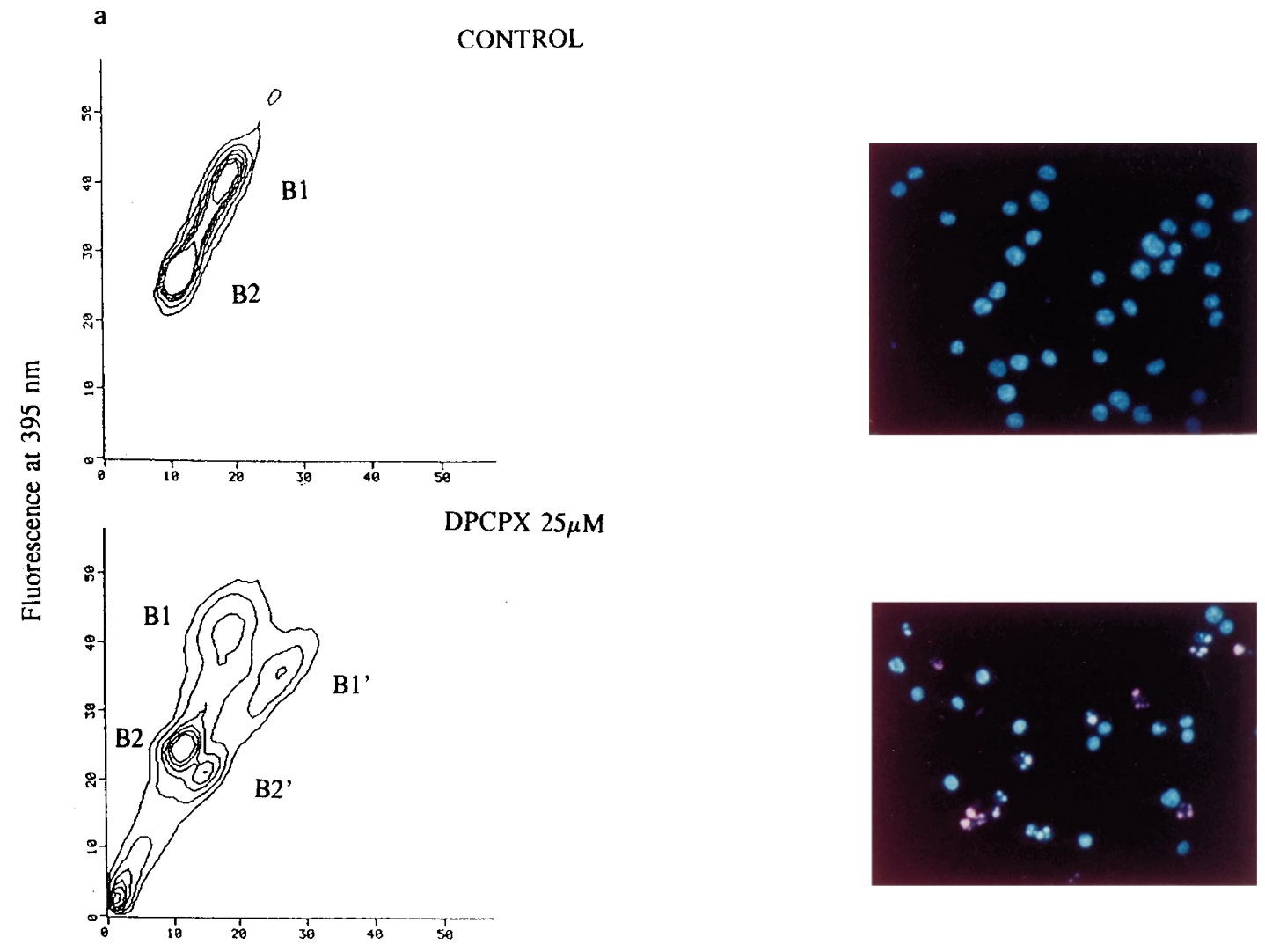

Fluorescence at $675 \mathrm{~nm}$

b
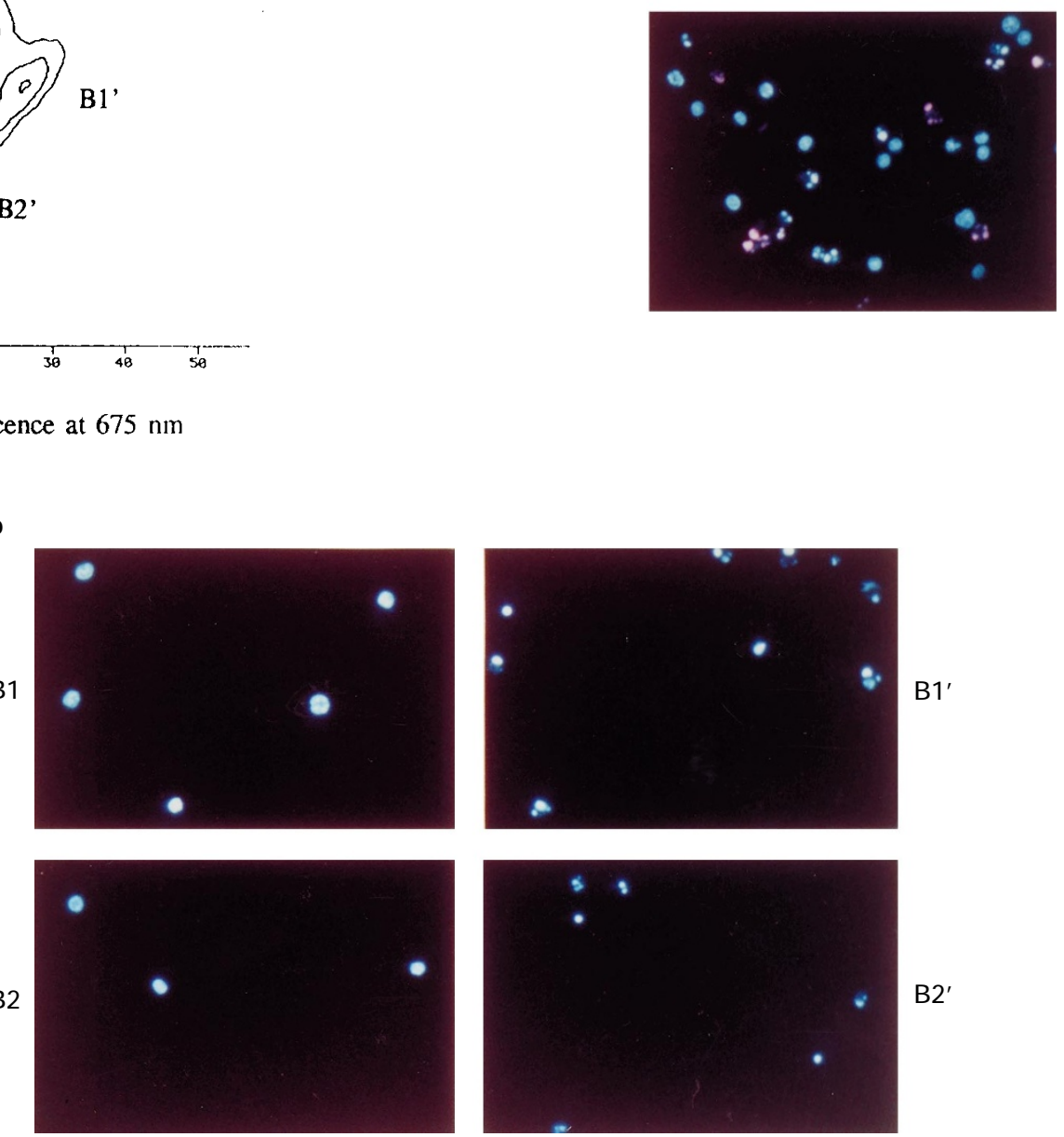

Figure 3 Nuclear morphology in DPCPX-treated cells. (A) Double fluorescence at 395 and $675 \mathrm{~nm}$ of cells (untreated or treated with $25 \mu \mathrm{M}$ DPCPX for $24 \mathrm{~h}$ ) labeled with Hoechst 33342 was analyzed. Insert: Image corresponding to the total cell population further labeled with propidium iodide. (B). Micrographs of sorted cells from populations B1, B1', B2 and B2' (See panel A). In this case analysed cells were not further labeled with propidium iodine 
a

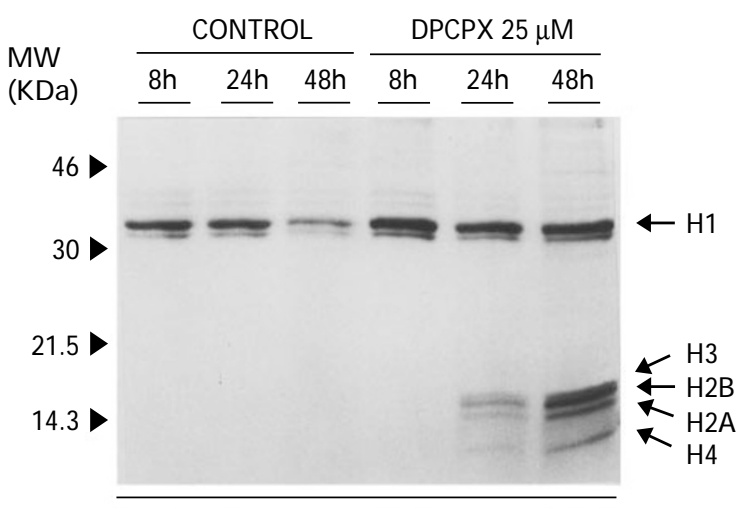

b

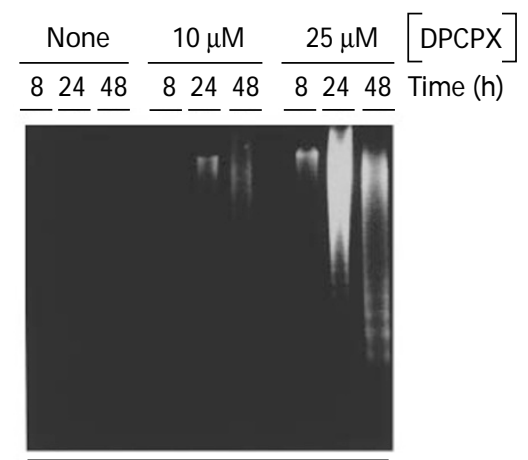

Figure 4 Biochemical changes in DPCPX-treated cells. (A) Polyacrylamide gel electrophoresis of nucleoplasm extracts from 5 million untreated or DPCPX-treated Jurkat cells. Histones H1, H2A, H2B, H3 and H4 are identified in the figure. (B) Agarose gel electrophoresis of low-molecular weight DNA extracted from 3 million untreated or DPCPX-treated Jurkat cells

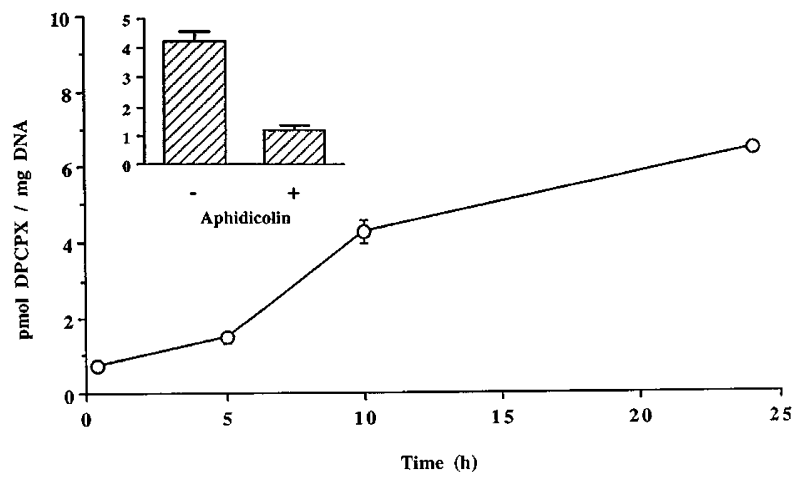

Figure 5 Accumulation of tritium from $\left[{ }^{3} \mathrm{H}\right] \mathrm{DPCPX}$ into nascent DNA. Radioactivity incorporated into DNA after incubation of cells $(5 \mathrm{million} / \mathrm{ml})$ with $22 \mu \mathrm{M}$ DPCPX and $\left.50 \mathrm{nM} \mathrm{[}{ }^{3} \mathrm{H}\right] \mathrm{DPCPX}$. Insert: Radioactivity incorporated into DNA after incubation with $\left[{ }^{3} \mathrm{H}\right] \mathrm{DPCPX}$ for $10 \mathrm{~h}$ in the absence or in the presence of $10 \mu \mathrm{g} / \mathrm{ml}$ aphidicolin

Neither compound was able to mimic the apoptosis provoked by DPCPX in Jurkat cells. On the other hand, $250 \mu \mathrm{M}$ N-ethylcarboxamido adenosine, a nonselective agonist of adenosine receptors, did not modify the percentage of cells with pycnotic nucleus after treatment with $25 \mu \mathrm{M}$ DPCPX for $24-72 \mathrm{~h}$; this indicates that adenosine receptors were not involved in the process.

If DPCPX does not act at the cell surface level there is a possibility that it enters the cell and affects DNA replication in a direct manner. Indeed, when tritiated DPCPX was added to Jurkat cells, there was a progressive incorporation of the radioactive label in the fraction of purified DNA (Figure 5). After $10 \mathrm{~h}$ of treatment, this incorporation was prevented by aphidicolin $(10 \mu \mathrm{g} / \mathrm{ml}$ of cell culture), a specific inhibitor of replicative DNA polymerases.

\section{Discussion}

The fundamental unit of chromatin in all eukaryotic cells is the nucleosome, which is constituted of approximately $200 \mathrm{bp}$ DNA. Histones $\mathrm{H} 2 \mathrm{~A}, \mathrm{H} 2 \mathrm{~B}, \mathrm{H} 3$ and $\mathrm{H} 4$ constitute the core of the particle and histone $\mathrm{H} 1$ is an extranucleosomal molecule that stabilizes DNA structure (Pederson et al, 1986). Adjacent nucleosomes are connected by the linker DNA which is an endonuclease-sensitive site. Programmed cell death activates nucleases, which produce DNA fragmentation and release of histones to the nucleoplasm (Laurent-Crawford et al, 1991). In this paper the DNA fragmentation and the release of histones induced in Jurkat cells clearly demonstrate that the xanthine analog, DPCPX, triggers apoptosis in cells from acute $T$ leukemia. We first hypothesized that signal transduction mechanisms at the plasma membrane level were involved in the activation of the death program. The lack of involvement of cell surface adenosine receptors was demonstrated by the absence of reversion of DPCPXinduced apoptosis by the nonselective agonist N-ethylcarboxamido adenosine. It was still possible that DPCPX interacted with other molecules at the cell surface level and produced a modification in the intracellular concentration of second messengers. Two of them, $\mathrm{Ca}^{2+}$ and cAMP, were investigated and their levels did not change in Jurkat cells upon incubation with the xanthine analog. The possibility that apoptosis was mediated by an inhibition of phosphodiesterases was ruled out after showing that other phosphodiesterase inhibitors, rolipram or milrinone, did not reproduce the apoptotic effects of DPCPX.

A possible indication of which was the mechanism of apoptosis was given by inspecting the evolution of the cell cycle pattern in DPCPX-treated cells which first suffered an arrest in $\mathrm{G}_{2} / \mathrm{M}$. It is not until 24 or $48 \mathrm{~h}$ that the apoptotic peak, previous to that of $G_{0} / G_{1}$, is clearly present. $A$ plausible interpretation of these results is that the reagent produces cell damage by a modification in the DNA. Subsequently, the cell activates the mechanisms of repair and upon their failure, it develops the death program. This interpretation is sustained by the incorporation of the radioactivity of $\left[{ }^{3} \mathrm{H}\right] \mathrm{DPCPX}$ into the purified DNA fraction. This incorporation was prevented by aphidicolin, which blocks DNA replication, and thus it is likely that a DPCPXderived nucleotide is incorporated into nascent DNA. Replication of DNA requires deoxyribonucleotide triphosphates and thus DPCPX should first incorporate the ribose-5'-phosphate moiety probably in a phosphoribosyl pyrophosphate-dependent way, i.e. by the purine salvage 
pathway. We tested hypoxanthine-guanine phosphoribosyl transferase as the activity that converts DPCPX into its ribose-phosphate derivative. The absence of inhibition by DPCPX of a commercial preparation from yeast (Sigma) and the lack of reversion of the apoptosis by hypoxanthine (which by itself had no effect, data not shown) indicate that this enzyme is not responsible for the reaction. Irrespective of the way DPCPX is incorporated into the nucleotide pool, it is not likely that a deoxynucleotide triphosphate version of DPCPX could enter into a de novo DNA strand. Thus, it would be possible that at some point of the intracellular metabolism of DPCPX the purine ring suffers some modification. One possibility is the incorporation of an amino group at position 2 of the purine ring, which would yield the 1,3-dipropyl-8-cyclopentyl-derivative of guanine. The deoxyribonucleotide triphosphate version of this guanine derivative would then be the compound that actually participates in DNA replication.

Belloc et al (1994) reported a red shift in the fluorescence emitted from apoptotic cells labeled with Hoechst 33342. When the fluorescence at 395 and $675 \mathrm{~nm}$ was analyzed in DPCPX-treated Jurkat cells, B1' and B2' populations appeared which were different from those found in control cells (Figure 3). These two cell populations presented a red shift and contained apoptotic cells (Figure 3 ). Similar red shifts in Hoechst 33342 fluorescence have been described in apoptotic rat thymocytes (Ormerod et al, 1993) and in antitumoralinduced apoptotic human polymorphonuclear cells (Belloc et al, 1994). The red shift has been used to detect 'early damaged' cells in murine cell populations and the differences in red fluorescence of intact and damaged cells have been attributed to differences in chromatin condensation (Ellwart and Dörmer, 1990).

Eastman et al (1994) have established the differences between physiological cell death and induced cell death. Activation of a glucocorticoid receptor or removal of a growth factor leads to 'physiological' apoptosis at the $G_{0} /$ $\mathrm{G}_{1}$ phase. In contrast, induced apoptosis can result from damage elicited at any phase of the cell cycle (Gorczyca et al, 1993; Eastman et al, 1994). The topoisomerase inhibitor, etoposide, causes an initial and rapid apoptosis in cells in phase $S$ and a slower apoptosis in cells progressing to $\mathrm{G}_{2}$. After $8 \mathrm{~h}$ DPCPX induce an arrest in $G_{2} / M$ in Jurkat cells; afterwards, there is a progression towards apoptosis that seems to be irrespective of the cell cycle. Accumulation of apoptotic cells in two peaks, one previous to that of $G_{0} / G_{1}$ an the other previous to that of $G_{2} / M$, supports this hypothesis. These results are similar to those obtained in HL-60 cells treated with the protein kinase $\mathrm{C}$ inhibitor, $\mathrm{H} 7$, or $\gamma$-radiation, since they underwent apoptosis in $\mathrm{G}_{2} / \mathrm{M}$ (Gorczyca et al, 1993). Of course, the possibility that the peak prior to that denoting the $\mathrm{G}_{2}$ / $M$ phase would correspond to an arrest in phase $S$ cannot be ruled out. In such a situation the results presented indicate that the apoptosis would occur at least in cells in phase $G_{0} / G_{1}$ and in cells in phase $S$. Accumulation of cells between the $G_{0} / G_{1}$ phase and the $\mathrm{G}_{2}$ phase has been reported in human leukemic U937 cells treated for $13 \mathrm{~h}$ with idarubicine and it has been interpreted as a block in the middle of the $S$ phase. It should be noted that the same cells, when treated with other chemotherapeutic drugs that induce apoptosis (camptothecin or aracytine), suffered a block in the early $S$ phase and accumulated in $G_{0} / G_{1}$ (Belloc et al, 1994). The cell death program triggered by DPCPX in leukemiaderived cells suggests that this reagent, like other apoptotic-inducing drugs, may be useful in the therapy of lymphoproliferative diseases of $\mathrm{T}$ origin.

\section{Materials and Methods}

\section{Materials}

1,3-dipropyl-8-cyclopentylxanthine (DPCPX) was from Research Biochemicals International (Natick, MA, USA). 2'-[4-ethoxyphenyl]-5[4-methyl-1-piperazinyl]-2,5'-bi-1H-benzimidazole (Hoechst 33342), 4,6-diamidino-2-phenylindole (DAPI), propidium iodide, ethidium bromide, bovine serum albumin (BSA), N-ethylcarboxamido adenosine, Triton X-100 and RNase were from Sigma Co. (St. Louis, MO, USA) and proteinase $\mathrm{K}$ was obtained from Boehringer Mannheim (Barcelona, Spain). All other products were of the best grade available and were purchased from Merck (Darmstad, Germany) and Sigma. Deionized water further purified with a Millipore Milli-Q system was used throughout.

\section{Cells and culture conditions}

Jurkat cells were maintained in RPMI 1640 medium (GIBCO; Grand Island, NY, USA) supplemented with $10 \%(\mathrm{v}: \mathrm{v})$ fetal calf serum (Boehringer Mannheim; Barcelona, Spain) $2 \mathrm{mM}$ L-glutamine and antibiotics (GIBCO; $100 \mathrm{U} / \mathrm{ml}$ penicillin, $100 \mu \mathrm{g} / \mathrm{ml}$ streptomycin and $0.25 \mu \mathrm{g} / \mathrm{ml}$ fungizone) at $37^{\circ} \mathrm{C}$ in a humid atmosphere of $5 \% \mathrm{CO}_{2}$. Cells were split to $5 \times 10^{5}$ cells $/ \mathrm{ml}$ to begin the experiments.

\section{Viability and proliferation assays}

Plasma membrane integrity was assessed in triplicate by trypan blue or propodium iodide exclusion and cell density was determined with a Coulter Multisizer particle counter (Coulter Corporation). $\left[{ }^{3} \mathrm{H}\right]$ thymidine incorporation assays were carried out in 96-well microtiter plates with flat-bottomed wells (Corning) in a total volume of $200 \mu$ l. Jurkat cells were incubated in triplicate with different concentrations of DPCPX for $24 \mathrm{~h}$ at $37^{\circ} \mathrm{C}$ in a $5 \% \mathrm{CO}_{2}$ humified atmosphere. At those times, $1 \mu \mathrm{Ci}$ of $\left[{ }^{3} \mathrm{H}\right]$ thymidine (24 Ci/mmol; Amersham) was added and cells were further incubated for $8 \mathrm{~h}$ before harvesting onto fiberglass filters. The amount of tritium incorporated into cellular DNA was assessed by scintillation counting using a Packard model TRI-CARB 1600 TR liquid scintillation counter.

\section{Assessment of apoptosis by biochemical techniques}

For analysis of internucleosomal DNA damage, cells (untreated or treated) were centrifuged at $200 \times \mathrm{g}$ for $15 \mathrm{~min}$ at $4^{\circ} \mathrm{C}$. Cell pellets were then treated with TTE solution $(10 \mathrm{mM}$ Tris/HCl pH 7.4, $1 \mathrm{mM}$ EDTA and $0.2 \%$ Triton $\mathrm{X}-100$ ), vigorously vortexed and centrifuged at $13000 \times \mathrm{g}$ for $10 \mathrm{~min}$ at $4{ }^{\circ} \mathrm{C}$ in order to separate fragmented DNA from intact chromatin. $0.1 \mathrm{M} \mathrm{NaCl}$ was then added to supernatants, which contained low molecular weight DNA, and precipitation was carried out overnight at $-20^{\circ} \mathrm{C}$ with isopropanol. 
Samples were then microcentrifuged at $13000 \times \mathrm{g}$ for $15 \mathrm{~min}$ at $4{ }^{\circ} \mathrm{C}$, and DNA pellets were washed with $70 \%$ ethanol, air dried and resuspended in TE buffer ( $10 \mathrm{mM}$ Tris/ $\mathrm{HCl} \mathrm{pH} 7.4,1 \mathrm{mM}$ EDTA) with $100 \mu \mathrm{g} / \mathrm{ml}$ RNase. DNA samples were analyzed by electrophoresis on $1.4 \%$ agarose gels containing $0.5 \mu \mathrm{g} / \mathrm{ml}$ ethidium bromide at $40 \mathrm{~V}$ for $1.5 \mathrm{~h}$. DNA ladder was observed under ultraviolet light. For nucleoplasm isolation and histone identification by polyacrylamide gel electrophoresis the method of Laurent-Crawford et al (1991) was used.

\section{Assessment of apoptosis by flow cytometry}

Cells were stained in the culture medium with $5 \mu \mathrm{g} / \mathrm{ml}$ Hoechst 33342 . After $30 \mathrm{~min}$ at $37^{\circ} \mathrm{C}$, cells were analyzed with an Epics Elite flow cytometer (Coulter Corporation; Hialeah, FL, USA). Hoechst 33342 was excited with the $333-364 \mathrm{~nm}$ lines of an argon ion laser at $25 \mathrm{~mW}$ and fluorescence was collected with $675 \mathrm{~nm}$ and $395 \mathrm{~nm}$ band-pass filters. For sorting experiments, cells were stained with the same procedure, and resuspended at $5 \times 10^{6} \mathrm{cell} / \mathrm{s} / \mathrm{ml}$ just before analysis and separation. Sorted populations were observed under a Zeiss Axioskop epifluorescence microscope (Germany) and photographs were taken with a Kodak-Ektachrome $160 \mathrm{~T}$ film. Propidium iodide and DAPI were also used to analyze cell cycle distributions. In both cases, aliquots of cells were removed from control and treated cultures at appropriate times and fixed in suspension in $70 \%$ ethanol at $-20^{\circ} \mathrm{C}$. Following fixation, $10^{6}$ cells were washed with PBS/BSA (PBS containing $1 \%(\mathrm{w} / \mathrm{v})$ bovine serum albumin). For propidium iodide staining, fixed cells were then resuspended in $1 \mathrm{ml}$ PBS/BSA containing $10 \mu \mathrm{g} / \mathrm{ml}$ propidium iodide and $0.1 \%$ RNase. Propidium iodide excitation was obtained with an argon ion laser adjusted to deliver $15 \mathrm{~mW}$ at $488 \mathrm{~nm}$, and fluorescence was detected using a $675 \mathrm{~nm}$ band-pass filter. When DAPI was used, cells were resuspended in $0.4 \mathrm{ml}$ of a solution containing $150 \mathrm{mM} \mathrm{NaCl}$, $80 \mathrm{mM} \mathrm{HCl}$ and $0.1 \%$ Triton $\mathrm{X}-100$ and kept for $10 \mathrm{~min}$ at $0-4^{\circ} \mathrm{C}$. Then $2 \mathrm{ml}$ of $180 \mathrm{mM} \mathrm{Na} \mathrm{HPO}_{4}, 90 \mathrm{mM}$ citric acid, $1 \mu \mathrm{g} / \mathrm{ml}$ DAPI, $\mathrm{pH} 7.4$, were added to each sample and fluorescence was measured. A UV laser with an excitation beam of $25 \mathrm{~mW}$ at $333-364 \mathrm{~nm}$ was used, and fluorescence was collected with a $525 \mathrm{~nm}$ band-pass filter. 20000 cells were counted for each histogram and cell cycle distributions were analysed with the Multicycle program (Phoenix Flow Systems, Inc.; San Diego, CA, USA).

\section{Incorporation of $\left.{ }^{3} \mathrm{H}\right] \mathrm{DPCPX}$ into DNA}

Jurkat cells were split to $5 \times 10^{6} \mathrm{cells} / \mathrm{ml}$ in fresh medium containing $22 \mu \mathrm{M}$ DPCPX and $50 \mathrm{nM}\left[{ }^{3} \mathrm{H}\right] \mathrm{DPCPX}(109 \mathrm{Ci} / \mathrm{mmol}$; New England Nuclear). At 0, 5, 10 and $24 \mathrm{~h}$, triplicate $1 \mathrm{ml}$ suspension samples were withdrawn for measurement of $\left[{ }^{3} \mathrm{H}\right] \mathrm{DPCPX}$ incorporation into DNA. In parallel, cells were preincubated in the presence of $10 \mu \mathrm{g} / \mathrm{ml}$ aphidicolin (Sigma) for $1 \mathrm{~h}$ before the addition of DPCPX/ $\left[{ }^{3} \mathrm{H}\right] \mathrm{DPCPX}$. Samples were collected after $10 \mathrm{~h}$ of treatment with the drug and DNA was purified as follows. Cells were centrifuged at 1400 r.p.m. for $5 \mathrm{~min}$ at room temperature and washed twice in $50 \mathrm{mM}$ PBS pH 7.4. Cell pellets were gently resuspended in $500 \mu \mathrm{l}$ of Hirt solution $(0.6 \%$ SDS, $10 \mathrm{mM}$ EDTA, $10 \mathrm{mM}$ Tris/ $\mathrm{HCl} \mathrm{pH} 7.4$ and $100 \mu \mathrm{g} / \mathrm{ml}$ proteinase $\mathrm{K}$ ) and incubated for $1 \mathrm{~h}$ at $37^{\circ} \mathrm{C}$. Then $1 \mathrm{M} \mathrm{NaCl}$ was added and samples were further incubated for $1 \mathrm{~h}$ at $0^{\circ} \mathrm{C}$. The suspensions were centrifuged at 15000 r.p.m. for $30 \mathrm{~min}$ at $4^{\circ} \mathrm{C}$ in a microfuge and the supernatants were extracted with one volume of phenol/chloroform (1:1) and one volume of chloroform. DNA was precipitated overnight at $-20^{\circ} \mathrm{C}$ with two volumes of ethanol and 0.1 volume of $3 \mathrm{M}$ sodium acetate $\mathrm{pH}$ 5.2. DNA pellets were then washed with $70 \%$ ethanol, allowed to dry in air and resuspended in $50 \mu \mathrm{l}$ of TE buffer. $40 \mu \mathrm{l}$ of each sample was added to $10 \mathrm{ml}$ of Formula 989 scintillation cocktail (New England Nuclear) and radioactivity of vials was counted. The nucleic acid content of each sample was determined spectrophotometrically by measuring absorbance at $260 \mathrm{~nm}$. Results of total DPCPX incorporation into DNA were expressed as pmol/mg DNA after correction for the DPCPX/[ $\left.{ }^{3} \mathrm{H}\right] \mathrm{DPCPX}$ ratio.

\section{Acknowledgements}

Supported by a joint (Echevarne Fundation and Spanish Ministry of Education) PETRI Grant (PTR92/0047) administered by Fundació Bosch i Gimpera and by Grants from Fondo de Investigaciones Sanitarias de la Seguridad Social (no. 87/1389 and 91/0272) and from CIRIT-CICYT (QFN93/4423). We acknowledge the help received from Dr. Jaume Comas, responsible of the flow cytometry section in the Serveis Cientifico Tècnics de la Universitat de Barcelona. We thank Robin Rycroft from the Servei d'Assessorament Lingüistic de la Universitat de Barcelona for the excellent technical assistance in the preparation of the manuscript. M. Mirabet is recipient of a fellowship of Formació d'Investigadors a Catalunya from Comissió Interdepartamental de Recerca i Innovació Tecnològica (CIRIT)

\section{References}

Belloc F, Dumain P, Boisseau MR, Jalloustre C, Reiffers J, Bernard P and Lacombe F (1994) A flow cytometric method using Hoechst 33342 and propidium iodide for simultaneous cell cycle analysis and apoptosis determination in unfixed cells. Cytometry 17: 59-65

Carrera CJ, Piro LD, Saven A, Beutler E, Terai C and Carson DA (1991) 2chlorodeoxyadenosine chemotherapy triggers programmed cell death in normal and malignant lymphocytes. In Purine and Pyrimidine Metabolism in Man VII, part A: Chemotherapy, ATP depletion and gout. RA Harkness, GB Elion and N Zöllner (eds.) (New York: Plenum Press) pp. 15-18

Cohen JJ (1993) Apoptosis. Immunol. Today 127: 126-130

Darzynkiewicz Z, Bruno S, DelBino G, Gorczyca W, Hotz MA, Lassota P and Traganos F (1992) Features of apoptotic cells measured by flow cytometry. Cytometry 13: 795-808

Dive C, Gregory CD, Phipps DJ, Evans DL, Milner AE and Wyllie AH (1992) Analysis and discrimination of necrosis and apoptosis (programmed cell death) by multiparameter flow cytometry. Biochim. Biophys. Acta 1133: 275-285

Duvall E and Wyllie AH (1986) Death and the cell. Immunol. Today 7: 115-119

Eastman A, Barry MA and Demarcq C (1994) The involvement of the cell cycle in apoptosis. In The cell cycle: Regulators, Targets, and Clinical Applications. V.W $\mathrm{Hu}$ (ed.) (New York: Plenum Press) pp. 369-378

Ellwart JW and Dörmer P (1990) Viability measurement using spectrum shift in Hoechst stained cells. Cytometry 11: 239-243

Fredholm B and Sandberg G (1983) Inhibition by xanthine derivatives of adenosine receptor-stimulated cyclic adenosine $3^{\prime}, 5^{\prime}$-monophosphate accumulation in rat and guinea-pig thymocytes. Br. J. Pharmacol. 80: 639-644

Gorczyca W, Gong J, ArdeltB, Traganos F and Darzynkiewicz Z (1993) The cell cycle related differences in susceptibility of $\mathrm{HL}-60$ cells to apoptosis induced by various antitumor agents. Cancer Res. 53: 3186-3192

Hentosh P and Grippo P (1994) Template 2-chloro-2'-deoxyadenosine monophosphate inhibits in vitro DNA synthesis. Mol. Pharmacol. 45: 955-961

Hitchings GH (1991) Biochemical approach to new medications. In Purine and Pyrimidine Metabolism in Man VII, part A: Chemotherapy, ATP depletion and gout. RA Harkness, GB Elion and N Zöllner (eds.) (New York: Plenum Press) pp. 1-6

Kizaki H, Suzuki K, Tadakuma T and Ishimura Y (1990) Adenosine receptormediated accumulation of cyclic AMP-induced T-lymphocyte death through internucleosomal DNA cleavage. J. Biol. Chem. 265: 5280-5284

Kvanta A and Fredholm BB (1991) CD3-dependent increase in cyclic AMP in human T-cells following stimulation of the CD2 receptor. Biochim. Biophys. Acta 1093: 178-183 
Laurent-Crawford AG, Krust B, Muller S, Rivière $Y$, Rey-Cuillé AA, Béchet JM, Montagnier L and Hovanessian AG (1991) The cytopathic effect of HIV is associated with apoptosis. Virology 185: 829-839

McConkey DJ, Hartzell P, Amador-Pérez JF, Orrenius S and Jondal M (1989) Calcium-dependent killing of immature lymphocytes by stimulation via the CD3/T cell receptor complex. J. Immunol. 143: 1801-1806

McConkey DJ, Orrenius S and Jondal M (1990) Cellular signalling in programmed cell death (apoptosis). Immunol. Today 11: 120-121

Ormerod MG, Sun XM, Snowden RT, Davies R, Fearnhead H and Cohen G (1993) Increased membrane permeability of apoptotic thymocytes: A flow cytometric study. Cytometry 14: 595-602

Pederson DS, Thoma F and Simpson RT (1986) Core particle, fiber and transcriptionally active chromatin structure. Annu. Rev. Cell Biol. 2: 117-147
Robertson LE, Chubb S, Meyn RE, Story M, Ford R, Hittelman WN and Plunkett W (1993) Induction of apoptotic cell death in chronic lymphocytic leukemia by 2 chloro-2'-deoxyadenosine and 9- $\beta$-D-arabinosyl-2-fluoroadenine. Blood 81 : $143-150$

Rothenberg EV (1990) Death and transfiguration of cortical thymocytes: A reconsideration. Immunol. Today 11: 116-119

Szondy Z (1994) Adenosine stimulates DNA fragmentation in human thymocytes by $\mathrm{Ca}^{2+}$-mediated mechanisms. Biochem. J. 304: 877-885

Tanaka Y, Yoshihara K, Tsuyuki M and Kamiya T (1994) Apoptosis induced by adenosine in human leukemia HL-60 cells. Experimental Cell Res. 213: 242252

Zhu L and Anasetti C (1995) Cell cycle control of apoptosis in human leukemic T cells J. Immunol. 154: 192-200 